\title{
Considering the Contradictions of Religion and Orthodox Christianity as concomitantly endorsing strife and accord - a Social Capital Perspective
}

\author{
Francois du Toit (RIP) \\ Graduate School of Business Leadership \\ University of South Africa \\ dutoitf@unisa.ac.za \\ Angelo Nicolaides \\ Department of Philosophy and Applied Ethics \\ University of Zululand \\ South Africa \\ nicolaidesa@unizulu.ac.za \\ http//:orcid.org/0000-0002-2153-2853 \\ Doi: https://doi.org/10.46222/pharosjot.10311
}

\begin{abstract}
This paper contributes to the existing literature by providing an discussion and a critique of the discourse of social capital as it relates to Christianity and in particular to an Orthodox stance. Religion is acknowledged as responsible for promoting factions in the world, as well as for the strife amongst the various religious groups. The New Testament is studied with the constituents of social capital - networks (groups), norms and trust - as a foundation for evaluating the ministries and teaching of Christianity with regards to the role thereof in promoting strife and unity and ultimately harmony amongst people. The ministry of Jesus Christ was distinctly opposed to the prevailing social capital in the then Jewish territories, as is the case in the epistles when speaking to the non-Jewish parishes. The prevailing normative principles were frequently censured, and the confrontational manner in which the established social groups were related to, aggravated by the entirely inclusive but absolutely exclusive standpoint, is deemed inexcusable and resulted in the execution of Christ and a number of his apostles and other followers. The threat to the trust amongst the Jewish citizens and also between the general population groups and religious leaders proved to be a major driving force in ongoing persecutions. Unity amongst the early Christians proved elusive and the absence of heterogeneity as a requirement for socially cohesive networks and groups served to explain this challenge. Diversity of ethnicity, language and culture impeded the spontaneous social associations. The epistles provide us with a rich account of the significance of diversity and the constant efforts towards unity and societal harmony. This is in concord with the Orthodox faith which is strongly in favour of acceptance of diversity and love for others. Social capital is an stimulating idea that has since biblical days become a focus for community advancement initiatives. The social capital perspective of the New Testament easily transcends into our reality of today and supports the relevance of Christian principles two thousand years later.
\end{abstract}

Keywords: Social capital, social groups, norms, Orthodoxy, inclusive and exclusive, diversity, unity.

\section{Introduction}

A number of studies demonstrate that religion is important for improving the indicators of accrual of social capital by communities globally (Filatov, 2005; Bourdieu, 1986). Putnam 
argues "First, religion is today, as it has traditionally been, a central fount of American community life and health. Faith-based organizations serve civic life both directly, by providing social support to their members and social services to the wider community, and indirectly, by nurturing civic skills, inculcating moral values, encouraging altruism, and fostering civic recruitment among church people" (Putnam, 2000). Our shrinking universe must be the single most significant phenomenon amongst all those we concern ourselves with at the global level, its effects are more tangible than even global warming and deforestation which are rampantly on the rise. The reality of a global village where inhabitants are interdependent and share a common fate has transcended mere theoretical arguments. China, once a disparate and isolated community, so aptly symbolised by the Great Wall of China, is today an integral part of the world economy.

Economic analysts are able to relay the impact of devaluation of the Chinese currency, or a slowdown in its economy, or a crash in its stock exchange, to hardships for economies and citizens the world over. Although the global village perspective implores cooperation and unity amongst countries and nations, a number of factors impede this. The referendum in Greece on its continued participation in the European Union, and the referendum in Scotland on its possible withdrawal from the United Kingdom, have served as sobering reminders that even unity founded in geographical proximity remains dubious. Except for extremist opinion, there is unanimous recognition of a need for unity of all peoples in God (Nicolaides, 2010), although views on which facets and extent thereof vary significantly. Mainline early Church Christians argue that the faithful have support in the intercessory prayers of the Virgin Mary and a hierarchical structure of Saints, who guide them to salvific acts of loving all people irrespective of creed, colour, gender, etc. (Nicolaides, 2014).

Over and above the obvious tensions created by the need to balance the interests of the national citizens with those of the collective in a cooperative endeavour, diversity presents as one of the factors which complicates effective and efficient cooperation. A force field analysis (Lewin, 1943 as republished 1997) is based on grouping forces as those that either promote unity, or those that oppose it. These forces are not static and the equilibrium thus remains fluid. This was the situation in New Testament Times as well when Sadducees and Pharisees contented with each other and all non-Jews. Lewin (1943, as republished 1997) emphasised the need to identify and overcome the opposing forces, as well as to strengthen the promoting forces, to positively influence the desired outcome which is of course a distinct Christian teaching of agape love. Today, identifying the sources of diversity amongst the peoples of the world is straight forward, a top-down approach distinguishes between the various sovereign countries firstly. For a fleeting moment, this "us against them" in the international arena may lull some into the euphoria that nations are indeed a homogeneous collective. South Africans, citizens of the Rainbow nation, are incessantly confronted by the forces of faction and the expressions thereof which often manifest in racial divisiveness and slander of the 'other'- all of which are antithetical to the principle of agape love.

Even when simply listing aspects of possible differences amongst people, the variables of culture and ethnicity rank highly just as the they did in the Roman Empire and other periods in global history. These include language, skin-colour, customs, values, religion and world views. Whereas most of these ethnic and cultural differences present as opposing forces to unity to a greater or lesser extent, religion presents as a unique contradiction. Although religion is inextricably part of culture, the basis for faction, the top five religions in the world all span national borders and all preach unity within (Hackett, Cooperman \& Ritchey 2015). Accepting the premise that in the human condition, religious convictions represent the dominant value system, how are the separatist tendencies amongst nations with a common religion explained? Even within the transnational representative bodies of religions, faction according to ethnicity and culture is found. In pursuit of unity, is religion an opposing force that should actively diminished, or is it a promoting force that needs to be emphasised? 
The discrepancy of religion as concomitantly uniting and separating will be explored by applying a social capital perspective to Christianity.

\section{Social capital and networks}

In broad terms, Parts (2004: 6) explains the concept of social capital as "... the institutions, social relationships, networks, trust and norms shaping the quality and quantity of a society's social interactions". Putnam (2000) was responsible for 'social capital' gaining universal acceptance, consisting of networks, norms and trust. The definitive literature is found in the decade spanning his work and the concept has subsequently been applied to various contexts. ${ }^{1}$ Several studies highlight the manner in which ties hinder innovation and deceive people in their networks. For others, in for example religious groups, it is a novel way of looking at social relations that can revolutionize thinking about society, with positive results promoting the notion of Christian agape as espoused by Jesus Christ. The current relatively new emphasis on social capital is lauded as bringing in social into economic development policies as a form of preserving sustainable religious and other communities (Edwards \& Onyx, 2007; Wakefield \& Poland, 2005). The discrepancy of religion as concomitantly uniting and separating will be explored by applying a social capital perspective to Christianity.

Networks are central to the phenomenon of social capital (Pollit, 2002). This study subscribes to the perspective that relations, and thus the trust and norms associated with social capital, reside in networks. This is borne out by the fact that preceding the universal adoption of the term social capital, it was referred to as networks, still used interchangeably since it is the network that exemplifies the norms and trust. We still network today to build social capital. The concept of networks, in the context of social capital, is synonymous with groupings of people in the social organisation of society. Groups are formed according to a variety of possible commonalities that people share. Some of these traits are discussed later.

Closed networks, as described by $\mathrm{Ng}$ (2004), consist of cohesive and frequent social interactions where every individual is directly or indirectly connected to the others. This property of closed networks creates a high density of social relationships that produces homogenous and clustering behaviours. It thus follows that, as a consequence, closed networks exhibit a normative environment with a high degree of social convention - the spinoff being by the reduction of uncertainty through trust. Ng's (2004) conclusions are that, from a relational perspective, the differences between closed and diverse networks are based on a social space reflecting near versus distant social relationships respectively.

In order for trust to evolve, it is further argued that repeated interaction between actors is pivotal in the establishment and sustainment of social capital. Healy (2004: 13) observes that trust is process-based (thus the requirement of repeated interaction), "... testing each other regularly, firstly on discreet exchanges of limited risk, then to more open-ended deals exposing parties to substantial risk. Trust thus develops over time; "Individuals learn by experience and update their expectations" (Ahn and Ostrom, 2008: 81). Searing (2013) distinguishes horizontal trust - interpersonal trust - from vertical trust or institutional trust. As a result of established trust relationships, organisational ties often result from personal ties. Konoirdos (2005: 4) credits trust as the bonding element of social capital, and, also as the bridging element between external networks. At societal level, it has been shown that in unequal societies, trust amongst individuals is at a low level (Jordahl, 2009). Grimalda and Mittone (2011) go as far as to conclude that trust in other people could be widely regarded as a key determinant for a society's economic performance.

\footnotetext{
${ }^{1}$ See Acqaah, Amoako-Gyampah, and Nyathi (2014) for Social Capital in South Africa
} 
Norms, and the ancillary normative aspects of relations, constitute cognitive social capital, including those common and shared goals which sustain group cohesion (Healy, 2004). He makes two pertinent observations regarding norms in relations:

1) that a sense of who one is, where one belongs and which norms of behaviour are acceptable, constitutes an important component of social interaction; and

2) significantly though, these rules of engagement are typically informal, tacit and probably not even consciously acknowledged or codified.

Social norms result from repeated interactions in which the particular norms are socialised and internalised by network participants. This is consistent with Healy's (2004: 13) observations on the evolution of trust noted before, reaffirming that trust and norms are inextricably linked. It could thus be argued that the congruency in norms significantly contributes to homogeneity of a network, and in doing so, it is responsible for the extent of exclusivity associated with a network.

Norms and trust are the pillars of reciprocity - the accumulation of obligations and interpersonal credits. Both Coleman (1990) and Putnam (2000) explain reciprocity as an obligation to repay an acquired debt originating from a positive action received by the self. Trust may be focussed towards specific people in which some confidence exist, such as family, friends and neighbours, or it may be people in general in a given neighbourhood or wider society where norms of reciprocity prevail. This confidence embodies the element of trust that these obligations will be honoured. Healy (2004) reiterates that trust and norms come together in reciprocity - as trust evolves, so do norms of reciprocity. Reciprocity arises from donation of favours, which, in turn, generate a series of expectations that one can rely on others to return in the future. The Coleman (1990) and Putnam (2000) perspectives reinforce Healy's (2004) perception of trust as a belief in the good intentions of others, or at least in their capacity to deliver on their promises and intentions; a product of mutual obligations. Reciprocity is crucial to social capital to the extent that Lin (2008: 59) has shown it to be a basis for grading of relations. Very close relations lead to the highest reciprocity expectations.

\section{Social factors of social capital}

In the seminal literature three variables of social organisation have been shown to be especially influential in forming social capital, namely proximity, relatedness and culture. Proximity reflects the fact that frequent exposure results from being in the same space, a prerequisite for development of social capital (Putnam, 2000). In their analysis of various studies on impersonal but frequent electronic communication (e.g. social media), Bachetti, Antonio and Faillo (2011: 243) note "a positive and significant correlation between the reduction of social distance and the frequency of non-selfish and cooperative choices". Relatedness is best understood by its direct manifestation as bonding social capital, where the relation facilitates the bonding, typically a result of connections and ties among families or specific ethnic or kinship-based groups (Edelman et al., 2004).

Bourdieu (1986) broadened the notion of social capital by introducing the role of culture. Putnam (2000) followed and included aspects of culture, beliefs and institutions in his perspectives on social capital. It follows then that cultural social capital will be identifiable (Hsung, Lin and Breiger, 2009). Expanding on the concept of culture, Putnam coined the terms "bonding social capital" (Putnam, 2000: 362) and "bridging social capital" (Putnam, 2000: 78). Bonding social capital refers to that facet of social networks that results from its characteristic of homogeneity (by class, creed, ethnicity, gender); whereas bridging social capital equates the transcending of the differences amongst members - the balance of those that are common - heterogeneity characteristic of a network. The relations and coherence of the group (network) is a continuously fluid equilibrium of bonding and bridging, of homogeneity and 
heterogeneity factors. Bridging social capital is especially relevant in linking of networks that share some members.

Coleman (1990) and Putnam (2000) emphasise the existence of conflict based on class or social interest. Warren (2008: 144) also refers to "cultural vulnerabilities" that are related to the normative rules and expectations embedded in networks, where ethnic communalism acts as a social trap for those within, and as bad social capital for those on the outside. Kristiansen (2004) sees a correlation between culture and the phenomenon of exclusivity, concluding that ethnicity, religion and class are common bases of faction. He perceives culture to be "a collective subjectivity, thus a shared set of values, norms and beliefs" (Kristiansen, 2004: 1151). Borgatti and Foster (2003) observe that physical proximity, the similarity of beliefs and attitudes and the amount of interaction and effective ties have all been found to be interrelated.

The phenomenon of homophily - resorting under the concept of social proximity and a function of homogeneity and exclusivity - describes the tendency of people to interact more with their own kind, whether by preference or induced by opportunity constraints (McPherson, SmithLovin and Cook, 2001). They concluded social proximity to be typically a function of similarity of individual characteristics such as race, gender, educational class and organisational unit. On the positive side, interacting exclusively with similar others is thought to be efficient since similarity facilitates transmission of tacit knowledge (Cross, Borgatti and Parker, 2001). It simplifies coordination and avoids potential conflicts (Healy, 2004). On the other hand, limited communication with dissimilar others prevents a group from reaping the benefits of diversity and promotes us-against-them thinking (Edelman et al., 2004). Homophily equates the inner layer of relations, and as relations transcend this inner circle, they are more heterophillous, assuming a bridging characteristic (Lin, 2008).

\section{Competing as a group}

It is not surprising that people are prone to group formation (networking) when considering their hierarchy of needs (Maslow, 1943 in McLeod, 2014). No group is absolutely homogeneous as differences are inevitable above the level of the individual. The distinguishing characteristics of a group extend beyond those of the individual being and often include social organisation, geographical location, and, common experiences or objectives. Typical groupings are families (based on kinship), communities (geographical proximity), organisations (shared objectives), ethnic groups (culture) and nations.

As social beings, humans are prone to social group formation and aspire to belong. As mentioned previously, there is a natural tendency towards homophily, the socialising amongst individuals and groupings that are similar, in preference to interacting with those that are different. Groups are also often the reason for a common characteristic, such as language or culture, the group is the source of the homogeneity and the group also sustains the homogeneity - effect, not cause. Spontaneity in social interacting is promoted in instances where actors have a lot in common. Groups are also not absolute and overlap extensively with members and groupings having multiple affiliations to other groups, depending on the characteristic that acts as basis for grouping.

The terminologies used to distinguish between groups are often overlapping, have a broad and narrow meaning, are used interchangeably and may lead to misunderstanding and some confusion. These bases for faction, or grouping, need to be clearly distinguished and understood if meaningful conclusions are to be derived. The following explanations highlight the differences and overlaps in meanings:

Nation: nationality, a politically organized nationality, e.g. a non-Jewish nationality a community of people composed of one or more nationalities and possessing a more or less defined territory and government

a territorial division containing a body of people of one or more nationalities and 
usually characterized by relatively large size and independent status a tribe or federation of tribes (as of American Indians)

Race: a family, tribe, people, or nation belonging to the same stock a class or kind of people unified by shared interests, habits, or characteristics a category of humankind that shares certain distinctive physical traits

Culture: the integrated pattern of human knowledge, belief, and behaviour that depends upon the capacity for learning and transmitting knowledge to succeeding generations the customary beliefs, social forms, and material traits of a racial, religious, or social group; also : the characteristic features of everyday existence (as diversions or a way of life) shared by people in a place or time <popular culture $>$ $<$ southern culture ...the set of shared attitudes, values, goals, and practices that characterizes an institution or organization (Merriam-Webster, 2015)

Ethnicity: of or relating to large groups of people classed according to common racial, national, tribal, religious, linguistic, or cultural origin or background <ethnic minorities > <ethnic enclaves >... being a member of a specified ethnic group <an ethnic German>... of, relating to, or characteristic of ethnics <ethnic neighbourhoods > <ethnic foods > (Merriam-Webster, 2015)

Nation, race, culture and ethnicity thus serve to emphasise the duality presented by differences amongst groups and the multiplicity of cross-membership.

Even today, where humanity has moved beyond the primordial strife for survival, the advantages contained in groups are well recognised. People band together and harness their combined efforts to achieve goals that would be impossible at the individual level (Kay, 2006). Shared norms and trust of a group also demarcate an environment towards which the individual is predisposed, feels a spontaneous affiliation, and is deemed to facilitate fulfilment of a hierarchy of needs (Maslow).

As with any form of power, the power of the group, as a competitive advantage of one group over another, also constitutes a threat to the non-dominant groups and is at risk of being abused. Social injustices could often be traced back to the principles of exclusivity of groups, the group as source of power to dominate and the pressure to conform to the norms in the group (Edwards \& Onyx, 2007). Racism, homophobia, Holocaust, nepotism, genocide and Apartheid are some examples of social phenomena which are closely related to group formation.

\title{
Religion in the context of group characteristics
}

Although religion is typically seen to resort under culture (Kristiansen, 2004), it is by now evident that in the context of social capital, networks based on religion potentially span networks based on a common culture. As is the case with race, culture and ethnicity, it is important that it is clear what is understood by religion which is...

\begin{abstract}
a set of beliefs concerning the cause, nature, and purpose of the universe, especially when considered as the creation of a superhuman agency or agencies, usu. involving devotional and ritual observances, and often containing a moral code for the conduct of human affairs.... a specific fundamental set of beliefs and practices generally agreed upon by a number of persons or sects: the Christian religion...the body of persons adhering to a particular set of beliefs and practices: a world council of religions...the life or state of a monk, nun, etc.: to enter religion...the practice of religious beliefs; ritual observance of faith...something a person believes in and follows devotedly. (Random House, 2010)
\end{abstract}

From the definition it is evident that religion is to a large extent a social phenomenon that is deeply rooted in the group where it also significantly finds expression, religion is practised in 
a group context. Religion, based in the characteristic of spirituality, has also evolved with the human race. Civilisation has meant the collection, recording and communicating of knowledge. Religions have spread similarly and span ethnic and cultural groups, and the dominant religions exhibiting a global footprint. Scholars such as King and Furrow (2004), and also Smith (2003) have hypothesised that religious engagement is a factor that contributes to overall levels of social capital in a community.

As related to earlier, the group is often both the source of a unique characteristic, and responsible for the maintaining of this characteristic (e.g. language), and the more isolated groups are, the more pronounced these differences are likely to become. Religion, in line with other characteristics such as language, literature, food, clothing, customs, behaviour, legal systems and norms, span group boundaries along other divisive characteristics. The term "Religious Capital" was advanced by an economist, and has most frequently been used mainly in economic contexts (Barker 2008). However, this role of religion in our lives can affect attitudes and behaviors which can impact health, potentially in a positive way.

The extent of the isolation of groups points to the importance of the spatial location of a group. Geographical remoteness or inaccessibility has historically been the main contributing factor to isolation of the group from diluting influences of others on the one hand, and also reinforcement as result of interaction limited to within the group on the other hand. Proximity is thus a requirement for interaction amongst members. Modern technology has all but overcome geographical remoteness and today isolation is mostly ascribed to consciously insolating behaviour such as ethnic segregation and religious exclusivity or fundamentalism.

Religion is a significant basis for factionalism. As can be logically deduced from the definition of religion, it is the choice of a belief-system to the exclusion of others, a value determination between right and wrong. Most religions claim to be uniquely true, all others to be false, and condemn non-believers. Religion is thus by nature exclusive. This was evident in Alexandria where the pre-Christian groups of Hellenes favoured their Greek philosophers and pantheon of gods as opposed to considering worship of the Egyptian deities, in whose land they lived. The same applied to the Jews in Alexandria who served YHWH as opposed to neither Egyptian nor Greek deities. As a lived social practise, religion is impacted on by the multitude of other factionalising characteristics that determine the existence of subgroups based on geography, language or ethnicity. These bounded subgroups sprout variations within a religion which as an inexact science is susceptible to interpretations.

\section{Social capital perspective on Christianity and an Orthodox perspective}

The ministries, teachings and enunciations on which Christianity ${ }^{2}$ is based, are considered from the constituents of social capital, namely networks, norms and trust, towards a novel perspective on the promotion of strife or unity. The New Testament is interrogated as an account of the ministries of Christ and the teachings of the apostles to guide Christians. Religious social capital includes the social resources available to individuals and groups through their social networks with a religious community. These resources comprise shared values, levels of trust among members of one's own religious group and religious hierarchy; and also levels of socializing that are specific to one's own religious group (Maselko et al., 2011). Orthodox Christianity has a strong link with tradition and with its past "For example, we may reflect on the importance attached to the first ecumenical councils or the teachings of the Fathers of the Church. It has succeeded in developing processes of modernization and in facilitating important historical changes, while maintaining nonetheless a set of reservations with respect to some typical demands (or basic elements) of the contemporary world." (Guglielmi, 2018).

\footnotetext{
${ }^{2}$ Although the term Christian is coined much later, it is applied retrospectively.
} 
The Eastern Orthodox Church standpoint is clear and its social doctrine is reflected in a document entitled 'For the Life of the World' which was recognized by its Holy Synod. The Church's central symbol and declaration of faith, the Nicene-Constantinopolitan Creed, Orthodox Christians confesses "one God, maker of heaven and earth, and of all things visible and invisible." Scripture affirms that "God saw everything that was made and, indeed, it was very good" (Genesis 1:31). The document touches on important aspects related to social life of believers in ecumenical relations, public spaces, human life and poverty, civil justice, peace and war, and human rights or the relationships between theology and science. Thus areas of interest include social life, geopolitics, the life of the church, the common good, peace and war or social discrepancies (Morariu, 2020). The responsibility of Christians in this world as they seek to transfigure fallen nature in service to the Kingdom, involves a real responsibility to the entire creation and a continual apprehension for its integrity and success. We need to approach the issues we face with prayerful discernment.

A study conducted in the Russian Orthodox Church on the analysis of the whole network of a parish proposes that active participation of parishes in organizing social work, based on the principles of delegating responsibility and executive powers from the priests to the laity, may go a large way in enlarging the social network of the parish as more laypeople are involved. This would serve to bring in many non-church attendees. For example, regular parish social activities, are especially important in promoting early religious socialization (Oreshina, et aj., 2015). People need to be instructed and guided thus all the constituents of our planet should be respected and those who are baptised should partake of the weekly celebration of the Holy Eucharist and this is a requisite activity of the Church because the Eucharist establishes the Church as the Body of Christ and since all are created in the imageo Dei, all of society becomes part of the Ekklesia (Church) (Nicolaides, 2010). The Eucharistic celebration by the faithful is then an act of communion, of the entire pleroma (body) of the Church, those past and present and are unified in eternity. The Holy Eucharist the is the source of her life, the superlative act of her thanksgiving and of her sacrifice of praise to the creator God (Nicolaides, 2021). The Holy Eucharist is the very core of Christian life, and the means by which each believer is nourished by God's grace and tender mercy.

There is also indication of a positive relationship between spiritual capital and health and wellbeing of a believer (Holt et al., 2012; Park et al., 2020). Trusting in God is very often explicitly declared as a member of a religious person's social support network (Kirkpatrick, 1998). Thus a believer has access to the Creator and this belief may have important health consequences, especially in the milieu of informing coping strategies in the presence of stressors like illness (Siegel \& Schrimshaw, 2002), familial issues, job loss and especially the onset of epidemics such as the Covid-19 which is currently plaguing our already troubled world. It is clear that all religious organizations are part of civil society (Bacon, 2006). The Orthodox Church champions "traditional values" norms around sexuality, reproductive health and gender. Their churches are habitually venues for social capital formation because people speaking the same Greek or Russian or whatever language, also share similar cultural codes and religious convictions and they tend to meet and exchange their ideas and experiences using familiar sociability norms. Orthodox church parishes endeavour to promote a climate of openness to the host society and emphasise the universal calling of their faith. In addition, Orthodox parishes are effective links between their populations and broader society to the extent that they are involved in a insightful positioning.

At the Divine Liturgy, the Church is continuously changed from a human community into the Body of Christ, the temple of the Holy Spirit, and the holy People of God. The interactions with the prevailing social establishment and communities, the normative environment and practises and the impact on relations between groups is noticeable as well as the directives regarding variables affecting people as Orthodox Christians (Florovski, 2009). The Apostle Paul pronounces that creation is "groaning in pain along with us from the beginning till now" 
(Romans 8:22), while "awaiting with eager longing" (Romans 8:19) "the glorious liberation by the children of God" (Romans 8:21). Religious participation if considered looking at the frequency of attending worship services, has been shown to be positively associated with membership in related religious organizations. Thus attending Orthodox services is also positively associated with fitting into certain types of non-religious voluntary organizations and community associations (Norris \& Inglehart, 2004) that are engaged in communities in which churches operate. The same researchers also found that membership in religious organizations (but not necessarily the attendance at religious services) was significantly associated with numerous indicators of civic engagement, including social attitudes and political behaviour (Norris \& Inglehart, 2004). The world we dwell in is a fallen order, fragmented and enslaved to sin and death, and distressed by violence and huge social injustices. We are called to serve God's Kingdom not this world (John 18:36), in service to a lasting loving peace that this world cannot give anyone (John 14:27). The earliest Christians were a community that was committed to a fundamental life of agape for all given that in Christ there is neither Jew nor Greek, neither slave nor free, nor any division in dignity between man and woman, because all are one (Galatians 3:28).

The community shared all things in common, and it provided for those in need, that permitted those with means to return to the common good the bounty they had reaped from creation (Acts $2: 42-46 ; 4: 32-35)$. No legal code is needed except love (Climacus, n.d.). The Orthodox Church recognises that society operates on different principles and that Christians have it in their power to remedy all social ills, albeit to a limited degree for any time and place. It argues that the Apostolic Church is the purest expression of Christian charity as a social logic and collective practice, and judges all human political and social activities in light of Christ's divinely ordained archetype. Christians need to participate in the political life of the societies in which they live, but need to do so always in true service to the justice and mercy of God's Kingdom. (Irenaeus of Lyons, 1997).

The Church does exist in the world, but is not of the world (John 17:11,14-15). Some believers may of course view their Orthodox faith communities principally as sanctuaries rather than a means to accessing their wider community for any particular reasons. Nonetheless, the Orthodox Church rejoices at every opportunity for encounter and reciprocal understanding between persons and all peoples. However, social capital is lost if understanding becomes impossible if certain voices are proleptically silenced by intimidating laws. Thus in the absence of needed understanding problems which are far worse and very often far more destructive than sheer civil disagreement can gestate and grow outside the margins of the public arena.

Accepting Orthodox faith and being bonded to a nation is a sort of modern synthesis that has characterised the relationship between church and nation in Orthodox (Roudometof, 2014). The Orthodox Church does accept the relegation of religious conscience and conviction to some purely private domain, if for no other reason than that its faith in God's Kingdom unavoidably shapes every feature of life for the faithful, including all the views of people on political, social, economic, moral and public issues. Concerning the ecological crisis, which is connected to climate change and global warming, it is considered obligatory for the Church to do everything within its spiritual power to protect God's creation from the consequences of human greed through social capital use (Mission §F.10, quoted in Sooy, 2017). In addition, the Orthodox Church view on healthcare is that it must be accessible to all (BSC §XI.3). It argues that hospitals are in fact "a Byzantine Christian invention, which developed alongside a robust public welfare system for the poor. By the late Byzantine era these were state run, and doctors were forbidden to accept payment for services...The Orthodox Church rejects discrimination," based upon "skin colour, religion, race, sex, ethnicity, and language." [Mission $\S E .2$ in Sooy, 2017]. The Church endorses "social justice" and "solidarity"... [Mission §§C.1, F, BSC VI.4 in Sooy, 2017). The Orthodox Church is also very critical of income disparity and confesses a synergetic relationship between the rights of labour and the well-being of the poor, 
and it is supportive of initiatives to create vigorous public welfare systems. This after all, was in place in the Byzantine empire. In addition the gap between rich and poor and the concentration of wealth in the hands of the few must be tackled [see Mission §F.4] (Sooy, 2017). For all this and far more needed initiatives to happen it is imperative to have networks together with shared norms, values and understandings that facilitate co-operation within or among groups of Orthodox believers. The relationships of mutual acquaintance and recognition should more or less be institutionalized (Bourdieu, 1983).

\title{
Totally inclusive but absolutely exclusive
}

Christianity, as a religion, presents in social capital terms as the basis on which a social group (network) is formed and is thus by definition exclusive. Christianity is also totally inclusive. Paul reaffirms this; "And he is the propitiation for our sins: and not for ours only, but also for the sins of the whole world." (1John 2:1-2), as does Timothy, "This is good, and it is pleasing in the sight of God our Saviour, who desires all people to be saved and to come to the knowledge of the truth." (1 Timothy 2:3-4).

Members of this all-inclusive Christian faith have but one single universally common conviction; "For God so loved the world, that he gave his only Son, that whoever believes in him should not perish but have eternal life." (John 3:16). Morrisson (2002:5) stresses this requirement to the exclusion of all else; "Christianity is a belief in a person. Not in a set of doctrines, a creed, or other statement of beliefs. Not in a liturgy or ritual. Not in an institution. Not in a program. Not even in Scripture, important though Scripture is. All these have their value. But the essential foundation of Christianity is belief in the person of Jesus Christ."

The counter of a single common conviction is that the absence thereof is also absolutely exclusionary. Jesus said to Thomas: "I am the way, and the truth, and the life. No one comes to the Father except through me." (John 14:6). Exclusion also extends to condemnation:

\begin{abstract}
Before him will be gathered all the nations, and he will separate people one from another as a shepherd separates the sheep from the goats. And he will place the sheep on his right, but the goats on the left. Then the King will say to those on his right, 'Come, you who are blessed by my Father, inherit the kingdom prepared for you from the foundation of the world, and these will go away into eternal punishment, but the righteous into eternal life. (Matthew 25:32-34,46)
\end{abstract}

It is hard to imagine a more factionalist stance towards other religious groups. A number of Christian practises and beliefs maintain and even exacerbate the social distance. Cross membership and multiple membership is not tolerated, exclusivity is the first of the Ten Commandments; "You shall have no other gods before me.", and, "You shall not bow down to them or serve them, for I the LORD your God am a jealous God," (Exodus 20:3-5). The apostles reaffirm this to Christians; "You cannot drink the cup of the Lord and the cup of demons. You cannot partake of the table of the Lord and the table of demons." (1 Corinthians 10:21). Christ makes it clear that Jewish descent does not secure salvation, "I tell you, many will come from east and west and recline at table with Abraham, Isaac, and Jacob in the kingdom of heaven, while the sons of the kingdom will be thrown into the outer darkness. In that place there will be weeping and gnashing of teeth." (Matthew 8:11-12).

In fact, absolute devotion is required, even at the expense of family, "If anyone comes to me and does not hate his own father and mother and wife and children and brothers and sisters, yes, and even his own life, he cannot be my disciple." (Luke 14:26), and of life itself, "Whoever loves his life loses it, and whoever hates his life in this world will keep it for eternal life." (John 12:25). Morrisson (2002:8) motivates for this devotion and obedience as inherent to "believing": In a nutshell, to believe, in the Biblical sense, means much more than intellectual acceptance. It means to commit one's self, to entrust one's self, and to obey. Faith that does not result in 
action is not real faith. And one of the actions which most clearly evidences our faith is obedience. Without obedience there can be no real faith."

Reed (2009:1) concludes that "Jesus was exclusionary as both $\mathrm{He}$ and His apostles were adamant that those who refused to do His Will would be excluded from His blessings, and openly warned that they would partake of His wrath." Christians also refer to themselves as "... God's chosen ones, holy and beloved, ..." (Colossians 3:12) which does not endear them to others.

Additionally, normative values and practises not in accordance to the Christian value system is labelled sin, and strongly disapproved of. Christ condemns those that do not repent: "Then he began to denounce the cities where most of his mighty works had been done, because they did not repent. "Woe to you, Chorazin! Woe to you, Bethsaida! For if the mighty works done in you had been done in Tyre and Sidon, they would have repented long ago in sackcloth and ashes." (Matthew 11:20-21). This doctrine inevitably leads to confrontation with nonChristians.

The way that Christ and the apostles relate to social capital in the New Testament sets the tone for Christianity. For the purpose of this discussion, two social contexts are discernible in the New Testament, firstly the historically Jewish territories into which Christ was born, lived and died, and where the first Christian congregation was established, and secondly, the nonJewish territories where the Apostles missioned. Although it is not suggested that the nonJewish territories were homogeneous, considering Jewish territories separately is motivated by the fact that Christ and his apostles were from the Jewish community. Just (2012:1) distinguishes between the ethnic, national and religious groups of the world during the life of Christ. Firstly, Ancient Jews, their ancestors, and their descendants; "Children of Abraham" people who claim Abraham as their father (whether literally or figuratively, by birth or by faith). This term can encompass Jews, Arabs, Muslims, Samaritans, and Christians. Secondly, terms used for Non-Jewish groups in the Ancient World; Samaritans - people from the region of Samaria, Gentiles - a general term referring to any and all people who are not Jews, and, Christians - not just one ethnic or national group, but all people who believe in Jesus as the "Christ".

The political environment was dominated by Roman occupation of Britannia, Spain, Gaul, Northern Africa and Asia Minor. During the life of Christ, social organisation of Israel and Judea was dominated by the Roman occupation and rule. Luke sketches the period as: "In the fifteenth year of the reign of Tiberius Caesar, Pontius Pilate being governor of Judea, and Herod being tetrarch of Galilee, and his brother Philip tetrarch of the region of Ituraea and Trachonitis, and Lysanias tetrarch of Abilene, during the high priesthood of Annas and Caiaphas, the word of God came to John the son of Zechariah in the wilderness." (Luke 3:12)

Antipas, who later took his father's name Herod, and had a Samaritan mother but was educated Roman, was instated as native ruler over Israel by the Roman Emperor, Augustus. The high priest Annas, ruled Judea during the birth of Christ, and was then afterwards succeeded by his son-in-law, Caiaphas. Pontius Pilate was Roman governor in Judea and had to contend with numerous violent Jewish uprisings (Gardner, 1981). Both Herod and Caiaphas - although by no means anti-Jewish - supported Pilate's efforts to oppress the outbreaks so as to prevent full-scale Roman retaliation: "So the chief priests and the Pharisees gathered the council and said, "What are we to do? For this man performs many signs. If we let him go on like this, everyone will believe in him, and the Romans will come and take away both our place and our nation." But one of them, Caiaphas, who was high priest that year, said to them, "You know nothing at all. Nor do you understand that it is better for you that one man should die for the people, not that the whole nation should perish." (John 11:47-50) 
Historically Abraham is viewed as the father of the Jewish nation, with whom God made a covenant that his offspring will be a great nation and that he will be their God. Up to the Egyptian enslavement of the Israelites (Jacob was called Israel), when they were under the oppressive rule of Pharaoh, there were no rulers above familial hierarchies and living in obedience to God constituted law. When Moses was called by God as leader to free Israel from Egypt a theocracy was established and God gave Israel his Ten Commandments and other laws described in Exodus and Deuteronomy. Israel lived as separate tribes according to kinship with the twelve sons of Jacob, each with its own territory. A number of religio-political groups were in existence in the Jewish territories, "Judaism at the time of Jesus was both unified and divided, much like Christianity is today. All Jews believed and practiced some core aspects of their religion (Monotheism, the Law of Moses, Circumcision, etc.), but different Jewish groups debated and disagreed with each other about many details (expectations of the Messiah, ritual and purity laws, how to live under foreign domination, etc.)" (Just, 2001:1). He describes the groups as follows; firstly those with a more religious emphasis, Pharisees a group of influential Jews active in Palestine from $2^{\text {nd }}$ century BCE through 1 st century CE; they advocated and adhered to strict observance of the Sabbath rest, purity rituals, tithing, and food restrictions based on the Hebrew Scriptures and on later traditions. Sadducees were another prominent group of Jews in Palestine from $2^{\text {nd }}$ century BCE through 1st century CE; they were probably smaller "elite" group, but even more influential than the Pharisees; they followed the laws of the Hebrew Bible (the Torah), but rejected newer traditions. The Essenes were a smaller group or "sect" that lived a communal "monastic" lifestyle at Qumran (near the Dead Sea) from $2^{\text {nd }}$ century BCE through 1 st century CE. They are not mentioned in the bible but the "Dead Sea Scrolls" found in this location in 1947 are associated with them. Then, the High Priest, Chief Priests, Priests, and Levites were members of the tribe of Levi who were responsible for the temple and its sacrifices, and thus were the religious and social leaders of the Jewish people. The Scribes were men specially trained in writing, and thus influential as interpreters and teachers of the Law, and agents of the rulers. The Elders were the "older men" of a community who formed the ruling elite and were often members of official "councils".

There were disciples of John the Baptist, during his lifetime and for several centuries thereafter, certain groups of people considered themselves followers of John the Baptist; some of them became Christians, but others maintained that John was earlier and more important than Jesus. The followers of Jesus of Nazareth - starting with smaller numbers of Jews in Galilee and Judea during his lifetime, those who believed in Jesus grew over the decades, spreading the "Jesus Movement" to other nations, cultures, and languages throughout the ancient Mediterranean. The two main politically-orientated were the Herodians, a faction that supported the pro-Roman policies and government of the Herodian family, especially during the time of Herod Antipas, ruler over Galilee and Perea during the lifetimes of John the Baptist and of Jesus. The Zealots were one of several different "revolutionary" groups in the 1st century CE who opposed the Roman occupation of Israel.

Even a common Roman oppressor failed to unify the Jews. Over and above the division that resulted from the Roman recognition of Judea and Israel under separate rulers, internal politics were also divided. The Herodians supported cooperation with the Roman occupiers, whereas populist uprisings were frequent. In the gospels we find reference to factions within Jewish religion such as Pharisees, Sadducees, and Lawyers, as well as cross-membership; "And when the crowd heard it, they were astonished at his teaching. But when the Pharisees heard that he had silenced the Sadducees, they gathered together. And one of them, a lawyer, asked him a question to test him." (Matthew 22:33-35). There were also a number of synagogues with dedicated membership: "Then some of those who belonged to the synagogue of the Freedmen (as it was called), and of the Cyrenians, and of the Alexandrians, and of those from Cilicia and Asia, rose up and disputed with Stephen."(Acts 6:8-9). The Roman occupation also revived the prophecies of the coming of the Christ that would free Israel (van der Watt and Tolmie, 2005). 
Some of the Pharisees were also Christians (Acts 15:5), most notably Paul, but also a Pharisee named Nicodemus, "a ruler of the Jews. This man came to Jesus by night and said to him, "Rabbi, we know that you are a teacher come from God, for no one can do these signs that you do unless God is with him." (John 3:1-2), and "Nevertheless, many even of the authorities believed in him, but for fear of the Pharisees they did not confess it, so that they would not be put out of the synagogue; for they loved the glory that comes from man more than the glory that comes from God. (John 12:42-43). Others were also positively disposed towards Jesus; "At that very hour some Pharisees came and said to him, "Get away from here, for Herod wants to kill you." (Luke 13:31)

Although the factions were not militantly opposed, some of the differences were fundamental and interaction even became physical (see Acts 23:7-10).

Through-out the Old Testament the fate of Israel was closely correlated with their devotion to God and the observance of his law. As has been the case during the numerous oppressions of the Old Testament, during Roman rule the normative environment was characterised by a general return to traditional Jewish practise, as an act of repentance, such as honouring the Sabbath, washing of hands and not mixing with other races (van der Watt and Tolmie, 2005). The seven pillars of Judaism (Just 2014:1) were; Election - the people of Israel are "chosen" by God; they are to be "holy" ("set apart"; different from other nations), Land - the "Holy Land" was "promised" by God to be theirs forever; a "land flowing with milk and honey", Monotheism - there is only One God (Deuteronomy 6:4), Law - core in "Decalogue" (10 Commandments); also the whole "Torah" (Five Books of Moses) and the whole Bible, Monarchy - the Davidic dynasty ("House of David") should reign as kings over Israel forever, Temple - the "House of God" should be in Jerusalem, so that God can dwell in the midst of his people, and, Messiah - when the covenants are broken, God will raise up an "anointed" leader to restore the nation to God, and to restore the earth to peace and justice with no more war, disease, death, etc. (exact expectations vary).

In such a fractioned society trust inevitably suffers. Herod, father of Antipas, executed three of his sons as a perceived threat to his throne, his son Archelaus was banished by the Emperor over his oppressive and harsh rule, and, Antipas and Caiaphas both openly supported Roman rule (Gardner, 1981). The Jewish council was made up of priests and elders and was headed by Annas, and the then High Priest Caiaphas, and they actively conspired with Judas Iscariot to betray Jesus and also brought false accusations against him (Mark 14:55-59).

\section{A new covenant}

How is it that Christianity is a crime against society (i.e. social capital) that would justify capital punishment for its proponents by crucifixion - Christ -, stoning - Stephen -, and the sword James? The essence of the clash between Christianity and the prevailing Jewish social norms is contained in the statement: "In speaking of a new covenant, he makes the first one obsolete." (Hebrews 8:13), Christianity professes the pervasive Jewish social capital to be obsolete. The existence of covenants was central to Judaism. Just (2014:1) relates five covenants in the Old Testament. The first two were for all people, those with Adam and Eve, and with Noah. Three covenants were made to the benefit of Jews exclusively, with Abraham, Moses and David. Although Christianity is an extension the Abrahamic religion, and the gospels emphasise the grounding in the prophecies of the Old Testament; "All this took place to fulfill what the Lord had spoken by the prophet: "Behold, the virgin shall conceive and bear a son, and they shall call his name Immanuel"3 (which means, God with us). (Matthew 1:2223), John the Baptist is said "For this is he who was spoken of by the prophet Isaiah when he said, "The voice of one crying in the wilderness: 'Prepare the way of the Lord; make his paths

\footnotetext{
${ }^{3}$ Isaiah 7:14
} 
straight." ${ }^{4}$ (Matthew 3:3). "Do not think that I have come to abolish the Law or the Prophets; I have not come to abolish them but to fulfil them." (Matthew 5:17). It does advocate a "new covenant" (Luke 20:20) that supersedes the previous Abrahamic covenant,

\begin{abstract}
"But as it is, Christ has obtained a ministry that is as much more excellent than the old as the covenant he mediates is better, since it is enacted on better promises. For if that first covenant had been faultless, there would have been no occasion to look for a second. For he finds fault with them when he says: "Behold, the days are coming, declares the Lord, when I will establish a new covenant with the house of Israel and with the house of Judah, not like the covenant that I made with their fathers on the day when I took them by the hand to bring them out of the land of Egypt. For they did not continue in my covenant, and so I showed no concern for them, declares the Lord." (Hebrews 8:6-9)
\end{abstract}

and this was rejected by Jewish society; "But their minds were hardened. For to this day, when they read the old covenant, that same veil remains un-lifted, because only through Christ is it taken away." (2 Corinthians 3:14). The covenant God made with Abraham was the basis of the Jewish normative system and any dogma nullifying it should reasonably expect harsh opposition. Just (2014:1) employs Jerimiah 31:31; "a new covenant with the house of Israel and the house of Judah" and terms it as the 'New or Renewed Covenant'.

Although the coming of the Christ is foretold in the Old Testament, and eagerly awaited, "So the Jews gathered around him and said to him, "How long will you keep us in suspense? If you are the Christ, tell us plainly." (John 10:24), the saviour was expected to deliver the Jews from their enemies, as is evident from the prophecies of Zachariah, father of John the Baptist;

\begin{abstract}
"Blessed be the Lord God of Israel, for he has visited and redeemed his people and has raised up a horn of salvation for us in the house of his servant David, as he spoke by the mouth of his holy prophets from of old, that we should be saved from our enemies and from the hand of all who hate us; to show the mercy promised to our fathers and to remember his holy covenant, the oath that he swore to our father Abraham, to grant us that we, being delivered from the hand of our enemies, might serve him without fear, (Luke 1:68-74)
\end{abstract}

From the second century BCE "apocalyptic, extreme messianism" (Schiffman, 2015:1) emerged amongst the Jews, and a number of the messianic figures came to the fore (van der Watt \& Tolmie, 1981: 390) to lead the uprisings against the various oppressors. Jesus Christ was not at all what Jews were expecting and thus the rejection of his teachings:

\begin{abstract}
"When they heard these words, some of the people said, "This really is the Prophet." Others said, "This is the Christ." But some said, "Is the Christ to come from Galilee? Has not the Scripture said that the Christ comes from the offspring of David, and comes from Bethlehem, the village where David was?" So there was a division among the people over him. Some of them wanted to arrest him, but no one laid hands on him." (John 7:40-44).
\end{abstract}

Schiffman (2015:1) concludes about Christ's crucifixion; "He died, because from the Roman point of view, he was guilty of sedition since the Romans understood his messianic claims and apocalyptic expectations of the kingdom of God on earth to be rebellious."

\title{
Christianity confronts
}

It is often hard to reconcile the essence of Christianity, a religion of love (1 Corinthians 13:4), of the grace of God - Christ suffering in our stead (Romans 5:15), love amongst fellow Christians (John 13:35) and even love for enemies (Matthew 5:44), with the forthright

\footnotetext{
${ }^{4}$ Isaiah 40:3
} 
confrontational stance of Christ towards the Jewish religious leadership, and Christian strife with the world (John 12:25) that is central to the gospels and the rest of the New Testament. Christ himself indicated the kind of internal friction within families and amongst Jews Christians could expect "Do not think that I have come to bring peace to the earth. I have not come to bring peace, but a sword. For I have come to set a man against his father, and a daughter against her mother, and a daughter-in-law against her mother-in-law. And a person's enemies will be those of his own household." (Matthew 10:34-36)

Christians are continuously engaged in an inner battle between good and evil, "For I know that nothing good dwells in me, that is, in my flesh. For I have the desire to do what is right, but not the ability to carry it out. For I do not do the good I want, but the evil I do not want is what I keep on doing." (Romans 7:18-19), and this extends to a battle with a sinful world, "Do not be conformed to this world, but be transformed by the renewal of your mind, that by testing you may discern what is the will of God, what is good and acceptable and perfect." (Romans 12:2). Paul relates to this as war, "Put on the whole armour of God, that you may be able to stand against the schemes of the devil. For we do not wrestle against flesh and blood, but against the rulers, against the authorities, against the cosmic powers over this present darkness, against the spiritual forces of evil in the heavenly places." (Ephesians 6:11-12)

The confrontational attitude of Christ and his apostles towards the Jewish social establishment is in essence an expression of intolerance of $\sin ^{5}$ : "He answered them, "And why do you break the commandment of God for the sake of your tradition?" (Matthew 5:13). Culture and tradition has eroded true devotion and the existing norms and practises are astray. Critical to the friction between Jews and Christians is the definition of $\sin$. In the Old Testament sin is seen as transgression of the commandments of God, So Moses returned to the LORD and said, "Alas, this people has sinned a great sin. They have made for themselves gods of gold" (Exodus 32:31) which God punishes, "keeping steadfast love for thousands, forgiving iniquity and transgression and sin, but who will by no means clear the guilty, visiting the iniquity of the fathers on the children and the children's children, to the third and the fourth generation." (Exodus 34:7), and, "Cursed be anyone who does not confirm the words of this law by doing them.' (Deuteronomy 27:26) and rewards for not sinning “... to fear the LORD his God by keeping all the words of this law and these statutes, ... so that he may continue long in his kingdom, he and his children, in Israel." (Deuteronomy 17:19-20). This understanding is reiterated in "As he passed by, he saw a man blind from birth. And his disciples asked him, "Rabbi, who sinned, this man or his parents, that he was born blind?" Jesus answered, "It was not that this man sinned, or his parents, but that the works of God might be displayed in him." (John 9:1-3). Christ expands sin (footnote 4), and thus reiterates that no one is just and thus no one can achieve salvation through works - obedience to the law. Reed (2009:1) states that "Jesus was confrontational in that he boldly told people the Truth, and He readily exposed sin, error, and lawless conduct. He was neither ashamed or afraid to confront those who rejected the gospel." Gatlin (2013) concurs; "Jesus was intolerant of sin and those who promoted it" and adds, "Jesus was confrontational toward those who knew the truth but rejected it."

In addition to creating awareness of pervasiveness of sin, Christ professes to be the Son of God, "This was why the Jews were seeking all the more to kill him, because not only was he breaking the Sabbath, but he was even calling God his own Father, making himself equal with God." (John 5:15-18), and "I and the Father are one. The Jews picked up stones again to stone

\footnotetext{
5 Transgression of the commandment of love for god and fellow man (Matthew 22:36-40); extended to include: Actions ("All wrongdoing is sin" ( 1 John 5:17); omissions, ("So whoever knows the right thing to do and fails to do it, for him it is sin" (James 4:17); thoughts, ("For out of the heart come evil thoughts"; "... looks at a woman with lustful intent has already committed adultery with her in his heart." (Matthew 5:19, 28); breach of conscience ("For whatever does not proceed from faith is sin. (Romans 14:23) (Ashley, 1997)
} 
him." (John 10:30-31), and even forgiving people their sins, "And when Jesus saw their faith, he said to the paralytic, "Son, your sins are forgiven." Now some of the scribes were sitting there, questioning in their hearts, "Why does this man speak like that? He is blaspheming! Who can forgive sins but God alone?" (Mark 2:5-7). A fundamental question remains, is the rejection of Jesus as the Christ the reason for rejecting his status as God, or were there no expectations of the Christ as God, but as a human, the reason for not accepting his divinity?

The normative distance exacerbates this friction as the Christian doctrine of grace and salvation through Christ is in direct confrontation with the performance religion of the Jews referred to in the preceding rebuke of the Lawyers - ; "yet we know that a person is not justified by works of the law but through faith in Jesus Christ, so we also have believed in Christ Jesus, in order to be justified by faith in Christ and not by works of the law, because by works of the law no one will be justified." (Galatians 2:16). "He was a threat to their conception of faith and national life, indeed, to the very existence of the Jewish people. If left unchecked, Jesus would either pervert the Jewish nation with his peculiar notions of the kingdom of God, or he would bring down the wrath of Rome upon Judea, leading to its destruction" Roberts (2010:18) concludes.

John the Baptist is the first to openly confront the religious leaders; "But when he saw many of the Pharisees and Sadducees coming to his baptism, he said to them, "You brood of vipers! Who warned you to flee from the wrath to come?" (Matthew 3:7). Christ was often downright confrontational; he frequently publically reprimands the religious leaders;

\begin{abstract}
He answered them, "And why do you break the commandment of God for the sake of your tradition? For God commanded, 'Honor your father and your mother,' and, 'Whoever reviles father or mother must surely die.' But you say, 'If anyone tells his father or his mother, "What you would have gained from me is given to God," he need not honor his father.' So for the sake of your tradition you have made void the word of God. You hypocrites! Well did Isaiah prophesy of you, when he said: "'This people honors me with their lips, but their heart is far from me; in vain do they worship me, teaching as doctrines the commandments of men."' (Matthew 15:3-9)
\end{abstract}

he condemns the actions of the Pharisees very harshly, calling them fools, greedy, wicked and unmarked graves, and then continues to denounce the Lawyers as well. (see Luke 11:37-54) Even the general population were often offended when Christ spoke out against them. (see John 11:7-8). Christ also told parables which more indirectly exposed the religious leaders, "And they came again to Jerusalem. And as he was walking in the temple, the chief priests and the scribes and the elders came to him, and, And they were seeking to arrest him but feared the people, for they perceived that he had told the parable against them. So they left him and went away." (Mark 12:12). It is evident that these were not subtle insinuations but the leaders were readily recognisable; "Then the disciples came and said to him, "Do you know that the Pharisees were offended when they heard this saying?" (Matthew 15:12)

The scribes and Pharisees depended to a large extent on their perceived superior knowledge of the Scriptures to validate their standing amongst the general population. Christ, "religiously illiterate" on numerous occasions exposes their inferior knowledge in public discourse. (see Mark 12:32-34)

He also confronts them directly regarding their lack of knowledge: "But Jesus answered them, "You are wrong, because you know neither the Scriptures nor the power of God. For in the resurrection they neither marry nor are given in marriage, but are like angels in heaven. And as for the resurrection of the dead, have you not read what was said to you by God: 'I am the God of Abraham, and the God of Isaac, and the God of Jacob'? He is not God of the dead, but of the living. And when the crowd heard it, they were astonished at his teaching" (Matthew 22:29-33). It is conspicuous that Christ and his disciples are questioned regarding their non- 
observance of social practices; And when the Pharisees saw this, they said to his disciples, "Why does your teacher eat with tax collectors and sinners?" (Matthew 9:11). Then the disciples of John came to him, saying, "Why do we and the Pharisees fast, but your disciples do not fast?" (Matthew 9:14 Then Pharisees and scribes came to Jesus from Jerusalem and said, "Why do your disciples break the tradition of the elders? For they do not wash their hands when they eat" (Matthew 15:1-2)."The man went away and told the Jews that it was Jesus who had healed him. And this was why the Jews were persecuting Jesus, because he was doing these things on the Sabbath" (John 5:15). Some of the Pharisees said, "This man is not from God, for he does not keep the Sabbath. But others said, "How can a man who is a sinner do such signs?" And there was a division among them. (John 9:16). Christ was aware that his non-observance of the Sabbath was contentious and that he was under scrutiny for it; "One Sabbath, when he went to dine at the house of a ruler of the Pharisees, they were watching him carefully. And behold, there was a man before him who had dropsy. And Jesus responded to the lawyers and Pharisees, saying, "Is it lawful to heal on the Sabbath, or not? But they remained silent. Then he took him and healed him and sent him away." (Luke 14:1-4)

Inevitably the confrontation with the Jewish normative status quo impacts the trust in social capital. Christ then also specifically warns society not to trust the Pharisees and the Sadducees; "Jesus said to them, "Watch and beware of the leaven of the Pharisees and Sadducees.", "Then they understood that he did not tell them to beware of the leaven of bread, but of the teaching of the Pharisees and Sadducees" (Matthew 16:6,12), and, "Then Jesus said to the crowds and to his disciples, "The scribes and the Pharisees sit on Moses' seat, so do and observe whatever they tell you, but not the works they do. For they preach, but do not practice." (Matthew 23:1-3). This correlates with the "cleansing of the temple" which is an indictment against the priests which the priests could not forgive. Roberts (2010:19) explains this, over and above the inference of the priests as robbers, by linking Christ's choice of "robber's den" to Jeremiah 7, "In the day of Jeremiah, the people had turned the temple into a "den of robbers," a place of supposed safety for those who did evil deeds out in the world. For this reason, God promised to destroy the temple."

From a social capital perspective it is not hard to appreciate that confrontations between Christ and the Jewish establishment could plausibly have contributed to his crucifixion. These confrontations motivate the decision to have Christ killed: "The Pharisees went out and immediately held counsel with the Herodians against him, how to destroy him" (Mark 3:6), and, "It was now two days before the Passover and the Feast of Unleavened Bread. And the chief priests and the scribes were seeking how to arrest him by stealth and kill him," (Mark 14:1) Roberts (2010:7) reiterates that Christ ultimately died at the hands of the Romans as only they had the right to execute by crucifixion, "Rome reserved crucifixion for the worst of criminals, especially for those who stirred up rebellion against the state. Because the point of crucifixion, beyond punishment, was deterrence, crosses were placed in public places so people would learn to fear the wrath of Rome." He also concludes that: "Thus it's historically accurate to speak, not of "the" Jewish perspective on the necessity of Jesus' death, but of several diverse Jewish perspectives. It's quite likely that the majority of Jews in Jerusalem did not want Jesus killed at all. But the perspective that had greatest impact on the fate of Jesus was that of Caiaphas and other principal leaders of Jerusalem." (Roberts, 2010:16)

Christians are obliged to engage the world on their faith "because, if you confess with your mouth that Jesus is Lord and believe in your heart that God raised him from the dead, you will be saved. For with the heart one believes and is justified, and with the mouth one confesses and is saved. (Romans 10:9-10), and Christ said: "So everyone who acknowledges me before men, I also will acknowledge before my Father who is in heaven, but whoever denies me before men, I also will deny before my Father who is in heaven" (Matthew 10:32-33). This is a principle acknowledged by all, "Peter said to him, "Even if I must die with you, I will not deny you!" And all the disciples said the same" (Matthew 26:34-35), as is the gravity of denying Christ, "And 
he went out and wept bitterly" (Luke 22:62). After Christ tells his followers that; "Whoever finds his life will lose it, and whoever loses his life for my sake will find it" (Matthew 10:39), "And do not fear those who kill the body but cannot kill the soul. Rather fear him who can destroy both soul and body in hell" (Matthew 10:28). He foretells the persecution that would follow in John 15:18-20.

The apostles remain steadfast in this instruction; "So they called them and charged them not to speak or teach at all in the name of Jesus. But Peter and John answered them, "Whether it is right in the sight of God to listen to you rather than to God, you must judge, for we cannot but speak of what we have seen and heard." (Acts 4:18-20), and Stephen becomes the first martyr (See Acts 7:51-57). The positive role that persecution of Christians in Jerusalem had in spreading the gospel is widely recognised as "And Saul approved of his execution. And there arose on that day a great persecution against the church in Jerusalem, and they were all scattered throughout the regions of Judea and Samaria, except the apostles." (Acts 8:1)

Interestingly enough, In the Bible there are only two accounts of persecution of Christians by non-Jews, and in both instances it was not on religious convictions, but motivated by commercial reasons. In Philippi, in the Roman colony of Macedonia, Paul and Barnabas were prosecuted, beaten and jailed following a charge by the owners of a slave girl for loss of income when they drove out a spirit of divination from her (Acts 16, 16-22). In Ephesus in Asia, the silver smiths feared a decline in demand for their statues of Artemis and Paul's companions Gaius and Aristarchus, both Macedonians, were charged, but the case was dismissed on grounds of jurisdiction. From the writings of the Roman historian, Tacitus, we find the first account of persecution of Christians by the Roman Emperor Nero in 64 A.D. with the execution of " ... a large number of Christians in an apparent effort to shift blame onto them for the fire that recently devastated the city." (Gardner, 1981: 207), so thus also not for pure religious convictions.

Although Herod's genocide of all boys under the age of two is directly attributable to the birth of Jesus Christ (Matthew 2:16), the first recorded persecution of a Christian is that of the man that was born blind and was given sight by Jesus (see John 9:28-34). The chronology is sometimes not strictly accurately reflected within and amongst the gospels, but the beheading of John the Baptist, although a Christian, is specifically ascribed to his criticism of Herod's marriage to his brother's wife.

There are some paradoxes in the gospels regarding the extent of the ministries of Christ on earth, exclusive - Jews only - versus inclusive - Jews and non-. When Canaanite woman begs Jesus to heal her sick child, "He answered, "I was sent only to the lost sheep of the house of Israel." (Matthew 15:24), and also, "These twelve Jesus sent out, instructing them, "Go nowhere among the Gentiles and enter no town of the Samaritans, but go rather to the lost sheep of the house of Israel." (Matthew 10:5-6). The apparent exclusive dedication to ministering to Jews is explained in the parable of the great banquet (Luke 14:16-24) where the slave first invites specific guests - Jews - and then everyone else that is prepared to except non-Jews. This perspective is supported when Christ says: "Thus it is written, that the Christ should suffer and on the third day rise from the dead, and that repentance and forgiveness of sins should be proclaimed in his name to all nations, beginning from Jerusalem" (Luke 24:4648). Then paradoxically, we read: "The Samaritan woman said to him, "How is it that you, a Jew, ask for a drink from me, a woman of Samaria?" (For Jews have no dealings with Samaritans.) So when the Samaritans came to him, they asked him to stay with them, and he stayed there two days. And many more believed because of his word." (John 4:9, 40-41) As reflected above, Christians are unanimous that Christ died for all people.

\section{Unity amidst diversity}

Christianity calls for unity amongst believers. There is a plethora of calls for unity in the New Testament which in itself is an indication of the extent of the challenge that it presents. Christ 
refers to a single "... kingdom prepared for you from the foundation of the world. (Matthew 25:34), and hints to a family, "In my Father's house are many rooms. If it were not so, would I have told you that I go to prepare a place for you? (John 14:2). Christ prays to the Father: "I do not ask for these only, but also for those who will believe in me through their word, that they may all be one.... (John 17:20-21)

The apostles continue to emphasise the importance of unity: "Rather, speaking the truth in love, we are to grow up in every way into him who is the head, into Christ, from whom the whole body, joined and held together by every joint with which it is equipped, when each part is working properly, makes the body grow so that it builds itself up in love" (Ephesians 4:1516). "There is one body and one Spirit-just as you were called to the one hope that belongs to your call-one Lord, one faith, one baptism, one God and Father of all, who is over all and through all and in all" (Ephesians 4:3-6). "I appeal to you, brothers, by the name of our Lord Jesus Christ, that all of you agree, and that there be no divisions among you, but that you be united in the same mind and the same judgment" (1 Corinthians 1:10) "until we all attain to the unity of the faith and of the knowledge of the Son of God, to mature manhood, to the measure of the stature of the fullness of Christ," (Ephesians 4:13) "making known to us the mystery of his will, according to his purpose, which he set forth in Christ as a plan for the fullness of time, to unite all things in him, things in heaven and things on earth." (Ephesians 1:9-10)

The call for unity is made with a sober recognition of the existing diversity amongst believers. (ss Colossians 3:11-14)

Even in Jerusalem, the congregation was a mix of Greeks and Jews; "Now in these days when the disciples were increasing in number, a complaint by the Hellenists arose against the Hebrews because their widows were being neglected in the daily distribution." (Acts 6:1) The challenge to unity is complicated across ethnic divides, but it is evident within ethnic groups. The existence of factions amongst Christians is found even during the life of Christ; "John said to him, "Teacher, we saw someone casting out demons in your name, and we tried to stop him, because he was not following us." But Jesus said, "Do not stop him, for no one who does a mighty work in my name will be able soon afterward to speak evil of me. For the one who is not against us is for us. (Mark 9:38-40). There is evidence that after John baptised Christ, he continued his baptisms and that John and Christ had distinct groups of followers. (see John 3:22-26). Just (2001:4) notes that the Disciples of John the Baptist was a significant grouping, both "during his lifetime and for several centuries thereafter, certain groups of people considered themselves followers of John the Baptist; some of them became Christians, but others maintained that John was earlier and more important than Jesus".

There is further evidence that the factions were formed according to the individual apostles that brought the Gospel "What I mean is that each one of you says, "I follow Paul," or "I follow Apollos," or "I follow Cephas," or "I follow Christ." Is Christ divided? Was Paul crucified for you? Or were you baptized in the name of Paul?" (1 Corinthians 1:12-13). This is similar to the experience in Iconium; ""The gods have come down to us in the likeness of men!" $\ldots$ and wanted to offer sacrifice with the crowds. But when the apostles Barnabas and Paul heard of it, they tore their garments ... " (Acts 14:11-14).

The normative values of Christians served to promote unity, significantly attributable to their deviation from the existing norms. There is evidence that the diversity of social capital amongst the various Christian groups resulted in strife which obliged the apostles to adjudicate, and not without disagreement and compromise.

The teachings in the bible address not only the philosophical considerations, but also a number of concrete daily aspects. These teachings are best explained by Christ's answer to the Pharisee regarding the great commandment, "And he said to him, "You shall love the Lord your God with all your heart and with all your soul and with all your mind. This is the great and first commandment. And a second is like it: You shall love your neighbour as yourself. On 
these two commandments depend all the Law and the Prophets." (Matthew 22:36-40). In essence it relates to either relations with God, or relations amongst people, dealing with dayto-day interactions.

The relations within the family unit, especially between husband and wife, are topical. John the Baptist symbolises the relationship between Christ and believers by stating; "The one who has the bride is the bridegroom. The friend of the bridegroom, who stands and hears him, rejoices greatly at the bridegroom's voice." (John 3:29), which is reverberated again; "Come, I will show you the Bride, the wife of the Lamb." (Revelation 21:9). Paul then also applies the inverse symbolism by equating the relations in marriage to those between Christ and his church. "Wives, submit to your own husbands, as to the Lord. For the husband is the head of the wife even as Christ is the head of the church, his body, and is himself its Saviour. Now as the church submits to Christ, so also wives should submit in everything to their husbands. Husbands, love your wives, as Christ loved the church and gave himself up for her' (Ephesians 5:22-25).

The first glimpse of the norms regarding marriage we encounter with the parents of Jesus Christ himself; "Now the birth of Jesus Christ took place in this way. When his mother Mary had been betrothed to Joseph, before they came together she was found to be with child from the Holy Spirit. And her husband Joseph, being a just man and unwilling to put her to shame, resolved to divorce her quietly." (Matthew 1:18-19). The law dictated death by stoning: "But if the thing is true, that evidence of virginity was not found in the young woman, then they shall bring out the young woman to the door of her father's house, and the men of her city shall stone her to death with stones," (Deuteronomy 22:20-21) Following a divine revelation, Joseph then goes against custom and marries the pregnant Mary; "But as he considered these things, behold, an angel of the Lord appeared to him in a dream, saying, "Joseph, son of David, do not fear to take Mary as your wife, for that which is conceived in her is from the Holy Spirit." (Matthew 1:20). Christ takes on the practise of divorce; "And Pharisees came up and in order to test him asked, "Is it lawful for a man to divorce his wife?" He answered them, "What did Moses command you?" They said, "Moses allowed a man to write a certificate of divorce and to send her away." And Jesus said to them, "Because of your hardness of heart he wrote you this commandment. But from the beginning of creation, 'God made them male and female.' 'Therefore a man shall leave his father and mother and hold fast to his wife, and the two shall become one flesh.' So they are no longer two but one flesh. What therefore God has joined together, let not man separate." (Mark 10:2-9)

Interestingly, the gospel according to Matthew adds justification for divorce; "And I say to you: whoever divorces his wife, except for sexual immorality, and marries another, commits adultery." (Matthew 19:9). Jesus reiterates that the marriage with a divorcee equates adultery; "And in the house the disciples asked him again about this matter. And he said to them, "Whoever divorces his wife and marries another commits adultery against her, and if she divorces her husband and marries another, she commits adultery." (Mark 10:10-12). The gravity of Christ's pronouncements are reflected by the despondent remark; "The disciples said to him, "If such is the case of a man with his wife, it is better not to marry." (Matthew 19:10). Paul confirms this; "To the married I give this charge (not I, but the Lord): the wife should not separate from her husband (but if she does, she should remain unmarried or else be reconciled to her husband), and the husband should not divorce his wife". (1 Corinthians 7:10-11).

Jesus then paradoxically, effectively saves an adulteress from death by stoning, by charging the first stone be thrown by the one without sin, and "Jesus stood up and said to her, "Woman, where are they? Has no one condemned you?" She said, "No one, Lord." And Jesus said, "Neither do I condemn you; go, and from now on sin no more." (John 8:10-11)

In the non-Jewish territories the strict sexual morality observed by Christians was conspicuous, "Let us walk properly as in the daytime, not in orgies and drunkenness, not in sexual immorality and sensuality, not in quarrelling and jealousy. But put on the Lord Jesus Christ, and make no 
provision for the flesh, to gratify its desires." (Romans 13:13-14), and, "Put to death therefore what is earthly in you: sexual immorality, impurity, passion, evil desire, and covetousness, which is idolatry." (Colossians 3:5)

It is also noticeable that Paul does not even mention the Jewish norm of abstinence during menstruation (Leviticus 20:18), but promotes total abstinence; "Now concerning the matters about which you wrote: "It is good for a man not to have sexual relations with a woman.", and "Now as a concession, not a command, I say this. I wish that all were as I myself am. But each has his own gift from God, one of one kind and one of another. To the unmarried and the widows I say that it is good for them to remain single as I am. But if they cannot exercise selfcontrol, they should marry" (1 Corinthians 7:1, 6-9). This aligns to Christ's remark regarding the merits of marriage; "But he said to them, "Not everyone can receive this saying, but only those to whom it is given. For there are eunuchs who have been so from birth, and there are eunuchs who have been made eunuchs by men, and there are eunuchs who have made themselves eunuchs for the sake of the kingdom of heaven. Let the one who is able to receive this receive it." (Matthew 19:10-12)

The strain that Christianity could possibly place on a marriage is evident; "But if the unbelieving partner separates, let it be so. In such cases the brother or sister is not enslaved. God has called you to peace. "(1 Corinthians 7:15), it led to divorce.

The relevance of prevailing norms is nowhere more evident than in the practise of slavery. Christianity clearly condoned slavery in the New Testament as an acceptable practise, whereas today it is perceived as an abomination by Christians. Paul does implore good relations, urges slaves to be content, but does not condemn the practise, even in cases where slaves are fellow Christians: "Let all who are under a yoke as bondservants regard their own masters as worthy of all honour, so that the name of God and the teaching may not be reviled. Those who have believing masters must not be disrespectful on the ground that they are brothers; rather they must serve all the better since those who benefit by their good service are believers and beloved. Teach and urge these things." (1 Timothy 6:1-2).

Paul even send a runaway slave, Onesimus, back to his master; "So if you consider me your partner, receive him as you would receive me. If he has wronged you at all, or owes you anything, charge that to my account." (Philemon 1:15-18). Although Paul states that all are equal in faith; "Here there is not Greek and Jew, circumcised and uncircumcised, barbarian, Scythian, slave, free; but Christ is all, and in all." (Colossians 3:11), he still advocates that the prevailing norms regarding women are observed, basing it in the Jewish Law, the same law he regards as dissolved: "the women should keep silent in the churches. For they are not permitted to speak, but should be in submission, as the Law also says. If there is anything they desire to learn, let them ask their husbands at home. For it is shameful for a woman to speak in church." (1 Corinthians 14:34-35).

Roman occupation of the civilised world had numerous positive outflows of which facilitating trade across pre-existing border was significant. This was actively encouraged by the Romans as the relied heavily on taxes from the occupied territories to fund their professional army. The tax burden was excessive and the Jewish tax collectors hated and branded as unclean. They were renowned for skimming taxes into their own pockets. Christ acknowledges this view when he says of one's brother that persists in sinning, "If he refuses to listen to them, tell it to the church. And if he refuses to listen even to the church, let him be to you as a Gentile and a tax collector." (Matthew 18:17). As an integral part of daily life, there are numerous accounts of Christ's interactions with tax collector's, his enunciations on the economic practises and his discourse with the Jewish leadership on this topic. Although the tax collectors were viewed as unclean and interactions or relations with them taboo for devout Jews, Christ frequently mingles and dines with them (Matthew 9:10). In fact, the very first disciple he calls, Matthew author of the gospel - is a tax collector he calls whilst sitting in his tax booth (Matthew 9:9), as 
was the case with Zacchaeus (Luke 19:2). The Pharisees rebuke Christ and his disciples for interacting with tax collectors (Matthew 9:11), but Christ in the parable of the son who does what he is told after first saying he will not, rebuts with: "Which of the two did the will of his father?" They said, "The first." Jesus said to them, "Truly, I say to you, the tax collectors and the prostitutes go into the kingdom of God before you." (Matthew 21:31), which they must have found extremely offensive. In the gospels we find the Pharisees and tax collectors as symbolic of self-righteousness and confessing sinners;

"Two men went up into the temple to pray, one a Pharisee and the other a tax collector. The Pharisee, standing by himself, prayed thus: 'God, I thank you that I am not like other men, extortioners, unjust, adulterers, or even like this tax collector. I fast twice a week; I give tithes of all that I get.' But the tax collector, standing far off, would not even lift up his eyes to heaven, but beat his breast, saying, 'God, be merciful to me, a sinner!' I tell you, this man went down to his house justified, rather than the other. For everyone who exalts himself will be humbled, but the one who humbles himself will be exalted." (Luke 18:10-14)

His reconciliatory stance towards the tax collectors is in contrast to his vocal aversion of the pervasive pursuit of financial gain and the Pharisees' love of money. He tells the parable of Lazarus and the rich ma, aimed at the Pharisees following: "The Pharisees, who were lovers of money, heard all these things, and they ridiculed him. And he said to them, "You are those who justify yourselves before men, but God knows your hearts. For what is exalted among men is an abomination in the sight of God." (Luke 16:14-15)

Christ cautions against pursuit of possessions and riches, firstly in the parable of the sower; "And others are the ones sown among thorns. They are those who hear the word, but the cares of the world and the deceitfulness of riches and the desires for other things enter in and choke the word, and it proves unfruitful." (Mark 4:18-19), but also:

\begin{abstract}
"Take care, and be on your guard against all covetousness, for one's life does not consist in the abundance of his possessions." (Luke 12:15), and "So is the one who lays up treasure for himself and is not rich toward God." (Luke 12:21), Jesus said to him, "If you would be perfect, go, sell what you possess and give to the poor, and you will have treasure in heaven; and come, follow me." When the young man heard this he went away sorrowful, for he had great possessions. And Jesus said to his disciples, "Truly, I say to you, only with difficulty will a rich person enter the kingdom of heaven. Again I tell you, it is easier for a camel to go through the eye of a needle than for a rich person to enter the kingdom of God." (Matthew 19:21-24) "But woe to you who are rich, for you have received your consolation." (Luke 6:24) "Sell your possessions, and give to the needy. Provide yourselves with moneybags that do not grow old, with a treasure in the heavens that does not fail, where no thief approaches and no moth destroys. For where your treasure is, there will your heart be also." (Luke 12:33-34).
\end{abstract}

Greed as the downfall of people is highlighted numerous times, most notably Judas Iscariot betrayal, "Then Judas Iscariot, who was one of the twelve, went to the chief priests in order to betray him to them. And when they heard it, they were glad and promised to give him money. And he sought an opportunity to betray him." (Mark 14:10-11). After the resurrection, soldiers were also bribed "And when they had assembled with the elders and taken counsel, they gave a sufficient sum of money to the soldiers and said, "Tell people, 'His disciples came by night and stole him away while we were asleep.' (Matthew 28:12-13). Ananias and his wife Sapphira, lied to Peter about the selling price of a property they sold and donated, both dying for it (Acts $5: 1-2$ ). Both Paul and James also reaffirm the dangers of greed (see James 5:1-6). 
Christ also awakened his disciples to value the widows contribution relatively, "Truly, I say to you, this poor widow has put in more than all those who are contributing to the offering box. For they all contributed out of their abundance, but she out of her poverty has put in everything she had, all she had to live on." (Mark 12:41-44)

The issues around payment of taxes are central in the efforts of the religious leaders to secure evidence for Christ's planned demise; "So they watched him and sent spies, who pretended to be sincere, that they might catch him in something he said, so as to deliver him up to the authority and jurisdiction of the governor." (Luke 20:20). It was a very contentious issue as Jewish sentiments very negative, and deterring its payment would lead to Roman prosecution. (see Mark 12:13-17)

The first encounter with tax collection is in Capernaum when Christ explains to Simon that the son of the King does not pay tax, "However, not to give offense to them, go to the sea and cast a hook and take the first fish that comes up, and when you open its mouth you will find a shekel. Take that and give it to them for me and for yourself." (Matthew 17:27). Paul relays this philosophy to the congregations:

\begin{abstract}
Let every person be subject to the governing authorities. For there is no authority except from God, and those that exist have been instituted by God. Therefore whoever resists the authorities resists what God has appointed, and those who resist will incur judgment. For rulers are not a terror to good conduct, but to bad. Would you have no fear of the one who is in authority? Then do what is good, and you will receive his approval, for he is God's servant for your good. But if you do wrong, be afraid, for he does not bear the sword in vain. For he is the servant of God, an avenger who carries out God's wrath on the wrongdoer. Therefore one must be in subjection, not only to avoid God's wrath but also for the sake of conscience. For because of this you also pay taxes, for the authorities are ministers of God, attending to this very thing. Pay to all what is owed to them: taxes to whom taxes are owed, revenue to whom revenue is owed, respect to whom respect is owed, honour to whom honour is owed. (Romans 13:1-7)
\end{abstract}

Christ clears the tables of trades from the temple, a symbol of the encroachment of pursuit of profit on devotion to God (Matthew 21:12-13). This ties in with his pronouncement that "No servant can serve two masters, for either he will hate the one and love the other, or he will be devoted to the one and despise the other. You cannot serve God and money." (Luke 16:13). The parable of the dishonest manager is to this day a very controversial one and is very hard to align to the morality of Christianity. (see Luke 16:8-12)

A significant variable in social capital is that of proximity and spatial relatedness. As indicated in the previous section, it facilitates interaction which is essential to social capital. There is a clear indication that Christians experience tension with the common social environment, "If you were of the world, the world would love you as its own; but because you are not of the world, but I chose you out of the world, therefore the world hates you." (John 15:19)

The segregation of Jews from the heathen nations is well described through-out the Old Testament; "For from the top of the crags I see him, from the hills I behold him; behold, a people dwelling alone, and not counting itself among the nations!" (Numbers 23:9), and, "Now then make confession to the LORD, the God of your fathers and do his will. Separate yourselves from the peoples of the land and from the foreign wives." (Ezra 10:11). The Jews observed the separation strictly, as reiterated by Peter, "You yourselves know how unlawful it is for a Jew to associate with or to visit anyone of another nation, but God has shown me that I should not call any person common or unclean." (Acts 10:28). Paul also confirms the absolution of Jewish exclusivity in preference for Christian inclusivity; "For as many of you as were baptized into Christ have put on Christ. There is neither Jew nor Greek, there is neither 
slave nor free, there is no male and female, for you are all one in Christ Jesus. And if you are Christ's, then you are Abraham's offspring, heirs according to promise. (Galatians 3:27-29), and, "Or is God the God of Jews only? Is he not the God of Gentiles also? Yes, of Gentiles also, since God is one-who will justify the circumcised by faith and the uncircumcised through faith." (Romans 3:29-30)

Although the Jewish exclusivity is thus absolved, it does not negate segregation from nonbelievers which remains intact (see 2 Corinthians 6:14-17). Paul then admits that absolute segregation is not practical, "I wrote to you in my letter not to associate with sexually immoral people - not at all meaning the sexually immoral of this world, or the greedy and swindlers, or idolaters, since then you would need to go out of the world." (1 Corinthians 5:9-10). The social organisation challenges the Apostles to the live-in realities of Christian religion, to non-Jewish Christians, Paul makes the directive of segregation subservient to the bond of marriage (see 1 Corinthians 7:12-16)

Peter emphasises the possibility that a spouse may promote conversion, "Likewise, wives, be subject to your own husbands, so that even if some do not obey the word, they may be won without a word by the conduct of their wives, when they see your respectful and pure conduct." (1 Peter 3:1-2). The conflicts experienced by Jewish Christians as a result of the entrenched religio-cultural practises are evident when Paul visits James and the elders in Jerusalem: "And they said to him, "You see, brother, how many thousands there are among the Jews of those who have believed. They are all zealous for the law, and they have been told about you that you teach all the Jews who are among the Gentiles to forsake Moses, telling them not to circumcise their children or walk according to our customs. Do therefore what we tell you. We have four men who are under a vow; take these men and purify yourself along with them and pay their expenses, so that they may shave their heads. Thus all will know that there is nothing in what they have been told about you, but that you yourself also live in observance of the law" (Acts 21:20-24).

Paul obliges in what could only be seen as a reconciliatory gesture, as this is in stark contrast to his own teachings: "For by works of the law no human being will be justified in his sight, since through the law comes knowledge of sin. But now the righteousness of God has been manifested apart from the law, although the Law and the Prophets bear witness to it" (Romans $3: 20-21)$. This is in opposition to Jewish convictions of salvation by upholding the law, "Therefore, since we have been justified by faith, we have peace with God through our Lord Jesus Christ. Through him we have also obtained access by faith into this grace in which we stand, and we rejoice in hope of the glory of God." (Romans 5:1-2). He similarly had Timothy circumcised to placate the Jewish Christians, as his father was Greek. (Acts 16:1-3).

Paul best explains his apparent compromise of his principles best when he urges Christians to transcend beyond the typical rules-based worship;

\begin{abstract}
"As for the one who is weak in faith, welcome him, but not to quarrel over opinions. One person believes he may eat anything, while the weak person eats only vegetables. Let not the one who eats despise the one who abstains, and let not the one who abstains pass judgment on the one who eats, for God has welcomed him. Who are you to pass judgment on the servant of another? It is before his own master that he stands or falls. And he will be upheld, for the Lord is able to make him stand. One person esteems one day as better than another, while another esteems all days alike. Each one should be fully convinced in his own mind. (Romans 14:15 ), For if your brother is grieved by what you eat, you are no longer walking in love. By what you eat, do not destroy the one for whom Christ died." (Romans 14:15)
\end{abstract}

There is evidence of a sensitivity amongst the Jewish Christians for ethno-cultural differences between Jews and the other nationalities; "We have therefore sent Judas and Silas, who 
themselves will tell you the same things by word of mouth. For it has seemed good to the Holy Spirit and to us to lay on you no greater burden than these requirements: that you abstain from what has been sacrificed to idols, and from blood, and from what has been strangled, and from sexual immorality. If you keep yourselves from these, you will do well. Farewell." (Acts 15:2729). Two variables emerge, the adoption of Jewish practises and the cessation of their own practises.

The spread of Christianity beyond the historical Jewish territories was to a large extent facilitated by the existence of segregated Jewish communities with synagogues - Antioch, Alexandria, Iconium, Thessalonica, Berea, Athens, Corinth and Ephesus - which the Apostles then visited and spread the gospel (Acts 13:14, 14:1, 17:1, 10, 17, 18:8, 19). In these territories the Christians congregations then consisted of a mixture converted Jews and locals. The cultural strife in the cities in the foreign countries are evident from letters: "Therefore let no one pass judgment on you in questions of food and drink, or with regard to a festival or a new moon or a Sabbath. These are a shadow of the things to come, but the substance belongs to Christ. Let no one disqualify you, insisting on asceticism and worship of angels, going on in detail about visions, puffed up without reason by his sensuous mind" (Colossians 2:16-18) and "For there are many who are insubordinate, empty talkers and deceivers, especially those of the circumcision party. They must be silenced, since they are upsetting whole families by teaching for shameful gain what they ought not to teach. One of the Cretans, a prophet of their own, said, "Cretans are always liars, evil beasts, lazy gluttons." This testimony is true. Therefore rebuke them sharply, that they may be sound in the faith, not devoting themselves to Jewish myths and the commands of people who turn away from the truth. (Titus 1:10-14)

The concept of homophily is central to the disagreement between Paul and Peter. Paul accuses Peter hypocrisy: "But when Cephas came to Antioch, I opposed him to his face, because he stood condemned. For before certain men came from James, he was eating with the Gentiles; but when they came he drew back and separated himself, fearing the circumcision party. And the rest of the Jews acted hypocritically along with him, so that even Barnabas was led astray by their hypocrisy. But when I saw that their conduct was not in step with the truth of the gospel, I said to Cephas before them all, "If you, though a Jew, live like a Gentile and not like a Jew, how can you force the Gentiles to live like Jews?" (Galatians 2:1114).

Deffinbaugh (2004:4) reads more into Peter's segregation than simple homophily. Firstly, the actions of Peter and the others were wrongly motivated. Secondly, the actions of Peter and the others caused some to stumble. Thirdly, the actions of Peter and the others were hypocritical. Fourthly, the actions of Peter and the rest were a practical denial of the gospel. Peter was conversely reprimanded by Jewish Christians for the exact opposite, "Now the apostles and the brothers who were throughout Judea heard that the Gentiles also had received the word of God. So when Peter went up to Jerusalem, the circumcision party criticized him, saying, "You went to uncircumcised men and ate with them." (Acts 11:1-3).

\section{Conclusions}

Social capital - networks, norms and trust - provide a novel platform from which the way in which Christianity promotes strife and unity can be explored, described and understood. The constituents of social capital are also inherent to our generation and this exposition of Christianity supports the application of the New Testament - the new covenant - in today's reality. A central human right is the protection of the principle of religious freedom including freedom of conscience, belief, and religion, inclusivity, alone and also in community, in private and in public spheres, the right to freedom of worship and practice, the right to make evident one's religion, as well as the right of religious communities to religious education and to the full purpose and exercise of their religious duties, without any method of direct or indirect intrusion by any state or other organ and yet in network with all. 
The context of the social networks and groups of the New Testament are readily recognisable in our current global context. War, oppression, global and national politicking, multiculturism, and divergent religious beliefs and practises to this day prevail. The pursuit of a global normative blue-print is still impeded by global diversity. The United Nations - all but united is grappling with the challenges of a unified approach to basic human rights, human trafficking, to environmental protection, to fair trade and to conformation to anti-oppressive political practices and equality of race and gender. In this supposedly technologically advanced age we have not even managed to eradicate hunger and poverty, Christs' words of two thousand years ago inevitably comes to mind: "For you always have the poor with you, and whenever you want, you can do good for them. But you will not always have me." (Mark 14:7)

Factionalism and religious extremism was once again stirred-up with the Gulf war of the Nineties and culminated in the infamous September 11 attacks. The war in Tunisia, Turkey and the Middle East fought by ISIS (Islamic State of Iraq and Syria), and the campaigns of posting Internet videos of beheadings of soldiers, civilians, journalists and aid workers, and its practise of destroying cultural heritage sites are trending in world news. The thousands of Syrian refugees have led to the implosion of international border crossings and tensions amongst the European countries, a real humanitarian crisis. The latest are claims by ISIS that strike fear in Christian countries:

\begin{abstract}
Islamic State, also referred to as IS and ISIS, is believed to be actively smuggling deadly gunmen across the sparsely-guarded 565-mile Turkish border and on to richer European nations, he revealed. They are following the well-trodden route taken by refugees and migrants fleeing, travelling across the border of Turkey then on boats across to Greece and through Europe. There are now more than 4,000 covert ISIS gunmen "ready" across the European Union, he claimed. He said: "It's our dream that there should be a caliphate not only in Syria but in all the world," he said "and we will have it soon, God willing." (Brown 2015:1)
\end{abstract}

This has led to a number of Islamic groups distancing themselves from ISIS.

Strife and unity within Christianity has to this day remained high on the agenda of discussions amongst the various leaders. Race, ethnicity, language, and dogma provide for diversity which impedes perfect unity. Yet, unity within diversity still remains elusive.

The social capital perspective reaffirms the relevance today of the ministries of two thousand years ago. The theoretical and biblical elements pronounced and evidence from the literature presented to support it can drive additional research to better comprehend the nature of the religious and especially Christian connection and its fundamental mechanisms in promoting religious knowledge, beliefs and faith-based linkages among adherents of the faith, that are connected to the Christian religion.

We require effective functioning of social groups through interpersonal relationships, including a shared sense of identity, understanding, norms, values, trust, cooperation, and also reciprocity. Social capital is then a measure of the value of resources, both palpable and imperceptible, and the impact that these relationships have on the resources involved in each relationship, and on larger groups in society. It must then be in line with agape, as a form of capital that produces public goods for a common usage. We need to recognise the great feats of the Orthodox church, its priests and adherents who globally build church organisations in the centre of extreme poverty, social exclusion and very often violence and pandemonium which is enveloping many nations. The priests, monks and missionaries exhibit extraordinary valour and integrity which bring hope and very often a sense of security to their parishioners. There is still much to be investigated, but is hoped that the article can at least provide ideas and incentive toward achieving the goal of a harmonious global community. By focusing on sound biblical religious traditions Christians have the potential to improve our troubled planet. 


\section{References}

Acqaah, M., Amoako-Gyampah, K. and Nyathi, N. Q. (2014). Measuring and Valuing Social Capital: A Guide for Executives, Network for Business Sustainability South Africa. [Online] Available: http://nbs.net/wp-content/uploads/NBS-SA-Social-Capital-ER.pdf. Accessed: 28 August 2015.

Ashley, S. (1997). How Does the Bible Define Sin? Beyond Today, United Church of God. [Online] [Available at: http://www.ucg.org/the-good-news/how-does-the-bible-define-sin].

Bacon, E. (2006) 'The Church and civil society in Russia', in Evans, Jr., A. B., Henry Laura A., and Mclntosh Sundstrom, L. (eds) Russian civil society: a critical assessment, Armonk, N.Y.; London: ME Sharpe, pp. 110-125.

Barker, M. (2008). The role of religious capital in relating religion and economic development. Third Sector Review, 14(1), 23-34.

Bercovitz, J. P. (2000). The History of Palestine in New Testament Times, Proceedings: Eastern Great Lakes and Midwest Biblical Societies. [Online] [Available: http://www.paulonpaul.org/booth/jewish_background.htm]

Bible English Standard Version. (2011) Crossway Bibles. on e-Sword® version 10.2.1.

Bourdieu, P. (1986). The Forms of Capital, In J. Richardson (Ed.). Handbook of Theory and Research for the Sociology of Education, New York: Greenwood

Bourdieu, P. (1983). "Ökonomisches Kapital, kulturelles Kapital, soziales Kapital." pp. 183198 in Soziale Ungleichheiten, Soziale Welt, Sonderheft 2, (Ed). R. Kreckel. Gottingen: Otto Schartz \& Co.

Brown, A. (2015). 'Just wait...' Islamic State reveals it has smuggled THOUSANDS of extremists into Europe. Daily and Sunday Express. [Online] [Available: http://www.express.co.uk/news/world/555434/Islamic-State-ISIS-Smuggler-THOUSANDS-

Extremists-into-Europe-Refugees]

Climacus, J. (n.d.). Ladder of Divine Ascent, Step 4.47. PG 88.705A.

Dale, A., \& Newman, L. (2010). Social capital: A necessary and sufficient condition for sustainable community development? Community Development Journal, 45(1), 5-21. https://doi.org/10.1093/cdj/bsn028

Deffinbaugh, R. L. (2004). Peter's Capitulation and Paul's Correction (Galatians 2:11-21). Bibleorg. [Online] [Available: online at https://bible.org/seriespage/6-peter-s-capitulation-and-paul-s-correction. Accessed: 26 August 2015

Edwards, M. \& Onyx, J. (2007). Social capital and sustainability in a community under threat, Local Environment, 12(1), 17-30]

Ekeke, E. C. (2013). The Greco-Roman and Jewish Contributions to the Growth of Earliest Christianity, American Journal of Social Issues and Humanities, 3(1).

Filatov S. (2005). Khristianskie religioznye soobshchestva Rossii kak sub'ekt grazhdanskogo obshchestva. [Christian religious communities of Russia as subjects of the civil society]. Otechestvennye zapiski [Notes of the fatherland]. 6(27).

Florovski, G. (2009). Sensul Ascezeicreștine (The sense of the Christian askesis), Patmos Press/

Gatlin, D (2013). Jesus: Intolerant, Confrontational, and Exclusionary, La Vista Church of Christ. [Online] Available: 
http://lavistachurchofchrist.org/LVarticles/JesusIntolerantConfrontationalAndExclusionary.ht m. Accessed: 28 August 2015

Guglielmi, M. (2018). Globalization and Orthodox Christianity: A Glocal Perspective, Religions, 9(7).

Hackett, C., Cooperman, A. and Ritchey, K. (2015). The Future of World Religions: Population Growth Projections, 2010-2050, Pew Research Center, April 2, 2015, [Online] Available: http://www.pewforum.org/files/2015/03/PF_15.04.02_ProjectionsFullReport.pdf. Accessed: 31 July 2015.

Harrington, E. (2015). Speaking in Tongues: The Language of Worship, Liturgy Brisbane. [Online] Available: http://liturgybrisbane.net.au/liturgylines/speaking-in-tongues-thelanguage-of-worship/. Accessed: 1 September 2015.

Holt, C. L., Schulz, E., Williams, B., Clark, E. M., Wang, M. Q. \& Southward, P. L. (2012). Assessment of religious and spiritual capital in African American communities, Journal of Religion and Health, 51(4).

Irenaeus of Lyons. (1997). On the Apostolic Preaching, Crestwood, NY: St Vladimir's Seminary Press, 1997,

Just, F (2001). Jewish Groups at the Time of Jesus, Catholic Resources for Bible, Liturgy, Art, and Theology. [Online] Available: http://catholic-resources.org/Bible/Jewish_Groups.htm Accessed: 26 August 2015.

Just, F (2012). Ethnic/National/Religious Groups in Biblical Times, Catholic Resources for Bible, Liturgy, Art, and Theology. [Online] Available: http://catholicresources.org/Bible/Ethnic_Groups.htm. Accessed: 26 August 2015.

Just, F (2014). Covenants, Pillars and Theologies in Ancient Judaism, Catholic Resources for Bible, Liturgy, Art, and Theology. [Online] [Available online at http://catholicresources.org/Bible/Covenants.htm Accessed].

Kay, A. (2006). Social capital, the social economy and community development. Community Development Journal, 41(2), 160-173. [Available online at https://doi.org/10.1093/cdj/bsi045]

Kesich, V. (2015). Conflict and Diversity in the Earliest Christian Community, Greek Orthodox Archdiocese of America. [Online] Available: http://www.goarch.org/ourfaith/ourfaith7126. Accessed: 27 August 2015

King, P.E. \& Furrow, J. L. (2004). Religion as a resource for positive youth development: religion, social capital, and moral outcomes, Developmental Psychology, 40(5).

Kirkpatrick, L. (1998). God as a substitute attachment figure: a longitudinal study of adult attachment style and religious change in college students, Personality and Social Psychology Bulletin. 24(9), 961-973.

Lewin K. (1943). Defining the "Field at a Given Time, Psychological Review, 50, 292-310. Republished in Resolving Social Conflicts \& Field Theory in Social Science, Washington, D.C.: American Psychological Association, 1997

MacLeod, S. A. (2014). Maslow's Hierarchy of Needs, Simple Psychology. [Online] Available: www.simplypsychology.org/maslow.html. Accessed 31 July 2015

Manns, F. (1998). Everyday life in the time of Jesus, The Holy Land, Autumn. [Online] Available: http://www.christusrex.org/www1/ofm/mag/TSmgenB3.html. Accessed 27 August 2015. 
Maselko, J., Hughes, C. \& Cheney, R. (2011). Religious social capital: its measurement and utility in the study of the social determinants of health, Social science \& medicine, 73(5), 759767.

Merriam-Webster (2015). Dictionary, Encyclopedia Brittanica company. [Online] Available: http://www.merriam-webster.com/dictionary/culture. Accessed: 31 July 2015.

Morariu, luliu-Marius. (2021). Towards the social doctrine of the Orthodox Church: The document 'For the Life of the World' of the Ecumenical Patriarchate (2020). HTS Theological Studies, 77(4), 1-6. \{Available online at https://dx.doi.org/10.4102/hts.v77i4.6545]

Morisson, J. L. (2002). Is Christianity Exclusive? Scripture Insights. [Online] Available: http://www.scriptureinsights.com/Exclusive.html. Accessed: 28 August 2015.

Nicolaides, A. (2021). Investigating the Holy Eucharist and the term 'people of God' according to the Eastern Orthodox Church, Pharos Journal of Theology, Volume 102.

Nicolaides, A. (2014). The Philosophical Conception of Mariology and the notion of the Theotokos in the teachings of saint Ambrose, Phronimon,15(2).

Nicolaides, A. (2010). The Laos tou Theou - an orthodox view of the "people of God", HTS Teologiese Studies/Theological Studies, 66(1).

Norris, P. \& Inglehart, R. (2004). Religious Organizations and Social Capital, from Sacred and Secular: Religion and Politics Worldwide. [Available online at https://www.icnl.org/resources/research/ijnl/religious-organizations-and-social-capital]

Oreshina, D., Prutskova, E. \& Zabaev, I. (2015) The Social Capital of Russian Orthodox Christianity in the Early 21st Century: Applying Social Network Analysis, State, Religion and Church, 2(2).

Ortberg, J. (2009). Life of Jesus - First Century Context of Palestine (Israel), Jesus Central [Online] Available: http://www.jesuscentral.com/ji/historical-jesus/jesusfirstcenturycontext.php Accessed 26 August 2015.

Park, J. J., Dizon Jude, P. M. \& Moya, M. (2020). Spiritual capital in communities of colour: Religion and spirituality as sources of community cultural wealth, The Urban Review, 52(1).

Putnam, R. (2000). Bowling Alone: The Collapse and Revival of American Community, New York: Simon and Schuster Paperbacks.

Random House. (2010). Kernerman Webster's College Dictionary, K Dictionaries Ltd.

Reed, D. L. (2009). Is Jesus Intolerant, Confrontational, And Exclusionary? Polk City Church. [Online] Available: http://www.polkchurch.com/Articles/PCP14_35.HTM. Accessed 28 august 2015

Reynal-Querol, M. (2002). Ethnicity, political systems, and civil wars, Journal of Conflict Resolution, [Online] Available http://sagepub.com. Accessed: 31 July 2015

Roberts, M. D. (2010). Why Did Jesus Have to Die? Roman, Jewish, and Christian Perspectives. Patheos. [Online] Available: http://www.patheos.com/blogs/markdroberts/series/why-did-jesus-have-to-die. Accessed 27 August 2015.

Roudometof, V. (2014). Globalization and Orthodox Christianity: The Transformations of a Religious Tradition, London and New York: Routledge.

Safran, W. (2008). Language, ethnicity and religion: a complex and persistent linkage, Nations and Nationalism, 14(1), 171-190. 
Schiffmann, L. F. (2015). Jesus, Prof Lawrence H Schiffmann [Online] Available: http://lawrenceschiffman.com/research/jesus/. Accessed: 28 August 2015.

Shapiro, E. A. (2021). Protective Canopy: Religious and Social Capital as Elements of a Theory of Religion and Health, Journal of Religious Health. [Available online at https://doi.org/10.1007/s10943-021-01207-8]

Siegel, K. \& Schrimshaw E. (2002). The Perceived Benefits of religious and spiritual coping among older adults living with HIV/AIDS, Journal for the Scientific Study of Religion, 41(1).

Smith, C. (2003). Theorizing religious effects among American adolescents. Journal for the Scientific Study of Religion, 42(1).

Sooy, N. (2017). Orthodox Social Thought: A Primer, Public Orthodoxy, Orthodox Christian Studies Center: Fordham University.

Tabor, J. (2013). The Jewish World of Jesus, UNC Charlotte [Online] Available: https://claspages.uncc.edu/james-tabor/the-jewish-world-of-jesus-an-overview/ Accessed 27 August 2015.

Warker, M. (ed) (2012). Paul, Jewish law and early Christianity, Biblical Archeologic Society. Washington, DC. 